\title{
Innovative Solutions for Building Envelopes of Bioclimatical High-rise Buildings
}

\author{
Elena Generalova, Viktor Generalov, Anna Kuznetsova \\ Samara State Technical University, Institute of Architecture and Civil Engineering \\ Address: Molodogvardeyskaya St., 194, Samara, 443001, Russia
}

\begin{abstract}
The paper examines innovative and promising trends in in the design of high-rise buildings that challenge traditional typologies and are adapted for specific climatic conditions. The purpose of the study is to investigate modern methods of designing building envelopes for bioclimatic skyscrapers taking into account heat impact of climate on the thermal balance of buildings.

The research methodology is based on a systematic analysis of advanced world experience in constructing innovative buildings, "conquering" climate. The paper provides the basic principles of bioclimatic architecture. The issues of buildings' forms and modes are considered. The authors analyze the efficiency of using double facades in different climatic conditions with account of their interaction with other technological, constructive and planning elements, such as "solar chimney", passive and active solar control systems, landscaping, intelligence control systems of temperature and humidity conditions in premises and buildings, etc.

The paper highlights that unique objects of bioclimatic skyscrapers are moving now into new typologies of buildings and help form dense, comfortable and convenient urban environment using natural resources effectively. The research shows how prospects and relevance of a systemic approach to introducing the related and interdependent projects for energy saving activities at all levels, starting from town-planning and architectural models, and ending with engineering and constructive solutions.
\end{abstract}

Keywords: bioclimatic architecture; double skin facade; high-rise buildings; natural ventilation.

\section{INTRODUCTION}

It is recognized globally that under intensive urbanization the traditional systems of forming the urban environment cause environmental, regional, social, economic, demographic and other problems. The urgent need to modify the existing approaches to designing buildings is becoming evident. That is why the bioclimatic trend is getting greater relevance in contemporary architecture and is actively used in high-rise construction. There are a lot of studies and published works trying to give the definition of the bioclimatic architecture and formulate its basic principles [1-12].

Summing up various definitions it can be said that in the framework of this concept nature does not perform as a passive backdrop for architecture anymore and is used as the inexhaustible source of energy opportunities. At that the ideas of creating harmony between architecture and nature are being developed. It means that consumer's attitude to the natural environment should be avoided. Buildings are designed in accordance with the unique regional, historical, cultural, environmental, infrastructural, social and economic features of a particular site development without causing any environmental damage. In this regard a building is considered as a unified energy system based on energy dependent principles. It effectively uses the potential of nature as a renewable energy source.

\section{II.MATERIALS AND METHODS}

It should be emphasized that high-rise construction is at the forefront of research. Huge energy consumption of traditional skyscrapers makes architects and engineers search for new, constructive systems, technologies and building materials. So a great number of scientific developments have been introduced in high-rise buildings in recent years. It allows extending the use of renewable energy and the efficient use of resources. More recently, the energy consumption of buildings has not been a defining quality factor of a design. Nowadays it is the dominant criterion in choosing the method for designing the thermal protection of building envelopes.

A key feature of bioclimatic high-rise buildings is their adaptability to the natural environment. It should be noted that despite the relevance of the topic, there are no researches systemizing various methods of buildings' adaptation to different climatic conditions. To study the building envelopes in high-rise buildings constructed in the regions with different climate is of special interest. It is necessary to keep in mind the importance of a systemic approach to the scientific research based on understanding an object as an 
integrated system consisting of a number of interrelated elements. Being a great energy consumer, a high-rise building is developed as a unified architectural engineering project. Therefore, it is impossible to examine the building envelope without analyzing its constructional and architectural planning features. It is very important to analyze engineering, heating, hot water, ventilation and air conditioning systems as well. Their optimal choice and combination depend on the external climatic conditions.

It is known that there are four main climatic zones in each hemisphere on our planet: equatorial, tropical, temperate and polar. There are transitional zones between main climatic zones: sub-equatorial, subtropical and subpolar. The following concepts related to climate features are used in climatology as well, i.e. mountain climate; arid climate of deserts and semi-deserts; humid subtropical climate; nival climate where not all the amount of solid precipitation can melt and evaporate. Climatic characteristics depend on a complex of astronomical and geographical factors. Major climatic factors are solar radiation, atmospheric circulation and topography. It should be noted that while designing high-rise buildings some special data should be taken into consideration. The values of outdoor temperature and outdoor barometric pressure are used in the calculations. These values are taken not only on the ground level, their changes height along are taken into account as well.

\section{RESULTS AND DISCUSSION}

In order to consider different climatic conditions the following high-rise buildings in equatorial, tropical, sub-tropical and temperate zones were taken for analyzing. While designing these unique buildings the experimental component was of great importance. At the experimental level they searched for the shape of buildings, the type of the whole building envelope and its elements, selection of building and finishing materials, etc. The analytical survey of the results obtained through introducing the principles of bioclimatic architecture is presented.

A. Experiments in designing façade systems of highrise buildings under the conditions of equatorial climate.

Equatorial climate is characterized by very little temperature and humidity changes throughout the year. Average annual temperature ranges from $+25^{\circ}$ $\mathrm{C}$ to $+31^{\circ} \mathrm{C}$. So it is always wet and hot, annual rainfall is about $2300 \mathrm{~mm}$. The concept of "a tropical skyscraper" in Singapore was created in such climatic conditions. The efforts of architects and engineers were focused on searching for the ways of using natural ventilation, double skin facades for protecting buildings from overheating by vertical landscaping as well. Systems for collecting rainwater are introduced, etc.

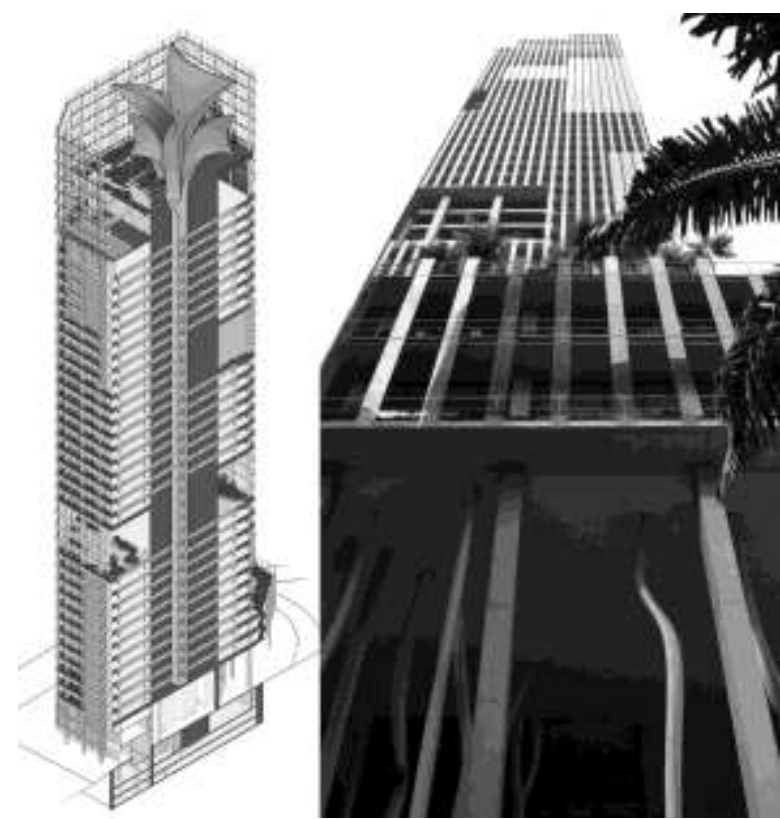

Fig. 1. «CapitaGreen», Singapore, Toyo Ito \& Associates [13].

The skyscraper "CapitaGreen" (242 m, 40 floors, completed in 2014) has a unique double skin façade system made from low-e glass, consisting of three main elements: 1-fragment monolithic frameless glazing of outer layer; 2- glazing unit of inner layer; 3-vegetation integrated in the interlayer space covers $55 \%$ of the façade (Fig. 1). The double skin façade is equipped with a wind scoop. It is an unusual element of the building's HVAC system made in the form of giant petals on top of the tower that reaches the height of $245 \mathrm{~m}$. At this height wind speed is higher while air temperature is lower. The wind scoop captures the wind flows and guides them into the cool void, located in the core of the building. It runs through all floors and delivers cool and fresh air there. The expected annual energy saving is $4563420 \mathrm{kWh}[13]$.

The hotel "Oasia Downtown" (206.6 m, 27 floors, completed in 2016) is another unique "green" skyscraper in Singapore. The basis of the bioclimatic concept is green façade that turns the high-rise building into an oasis, a tropical "living tower" in the dense urban environment. The task of constructing a great number of open end-to-end spaces in the form of green terraces in the tower was solved. For this purpose a non-standard construction system was developed. The system includes four stiffening cores located at the corners instead of one central core. This solution is directed not only at achieving visual transmission, but provides excellent natural cross ventilation. Thus, all public open spaces are provided with comfortable conditions, optimal microclimate, natural lightning and fresh air. As in the previous example the building envelope represents an unusual double skin façade. The outer layer is a red aluminum mesh. Tropical plants sprout through it (Fig. 2). 


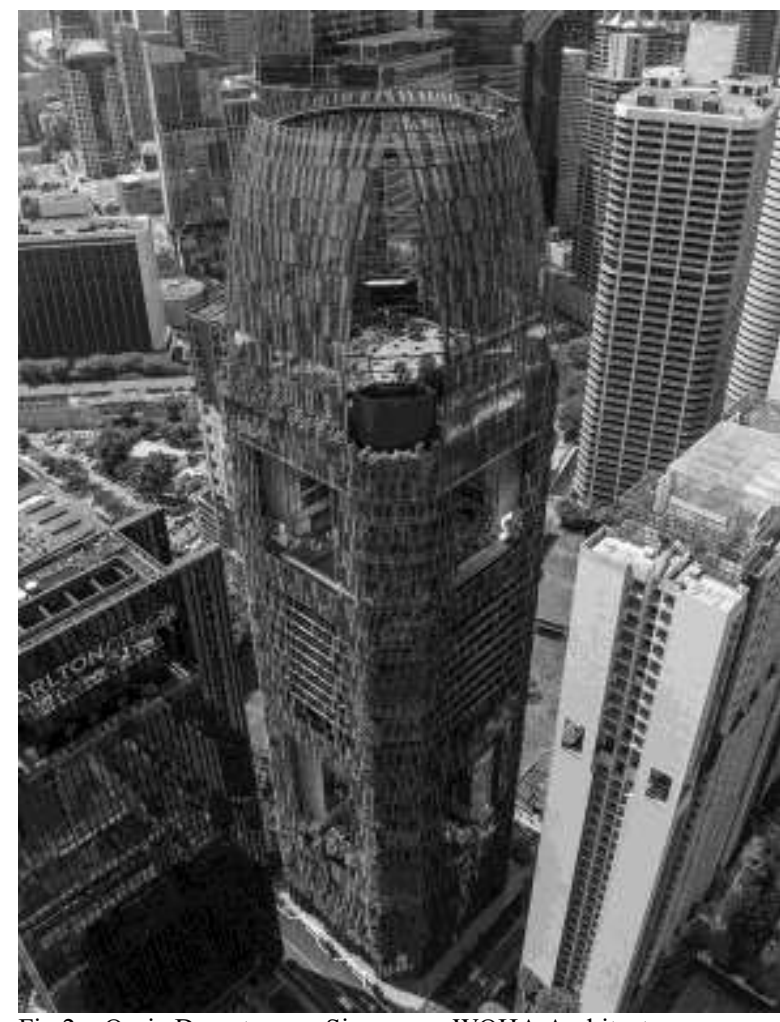

Fig.2. «Oasia Downtown», Singapore, WOHA Architects.

B. Experiments in designing façade systems of highrise buildings under the conditions of tropical desert climate

In the United Arab Emirates high-rise construction is developed under the conditions of very hot and dry climate that can be called tropical desert climate. This kind of climate has the following characteristics: sand storms; the average summer temperature in the shade is from +40 to $+50^{\circ} \mathrm{c}$; daytime winter temperature is from +20 to $+23^{\circ} \mathrm{C}$; it is cooler at night; rainfall is irregular, annual rainfall is about $100 \mathrm{~mm}$. The environmental strategy is to minimize the negative climatic effects of high temperature on the building by reducing greatly the use of air conditioners for creating comfortable conditions inside the building.

"The Index" (326 m, 80 floors, completed in 2011) is one of the first bioclimatic skyscrapers in the Middle East (Fig. 3a). The structure has four powerful A-concrete frames that in addition to bearing functions form the selfshading plastic of the façade. The basis of the unique system of airconditioning is the position of the skyscraper exactly to east-west. The east and the west facades are exposed to low and deeply penetrating rays of the morning and afternoon sun. Therefore, in the office block staircase and elevator units are located on the east and west facades blocking the sunlight. The residential block in the west and in the east is protected by impressive bulging concrete pylons that create a shading effect, preventing overheating of the premises. The southern glass façade of the office block is protected from the noon sun rays that have low penetrating power by fixed sunshade shelters with a large console eave. Deep loggias are added on the southern façade in the residential part of the building. Orientation, planning structure and plastic of the tower façade is performed so that the temperature does not exceed $28^{\circ} \mathrm{C}$ in the premises at the height of summer without any air conditioners.

The high-rise complex "Sowwah Square" in Abu Dhabi (131, 155 m; 31, 37 floors, completed in 2012) can be taken as an example of designing building envelopes as a combined system. The facades represent the integration of three technologies: ventilated double skin façade, passive shading and active shading. Active shading is presented by movable shutters, reacting to the sunlight intensity. Thanks to these efforts, the average temperature in the air gap of the double skin façade does not exceed $+32^{\circ} \mathrm{C}$ while temperature outside reaches $+46^{\circ} \mathrm{C}$. The calculations showed that the double skin façade in "Sowwah Square» saves $\mathrm{kWh} / 7200$ of electric power a day and provides more comfortable temperature environment close to the wall perimeter [14] (Fig. 3b). 

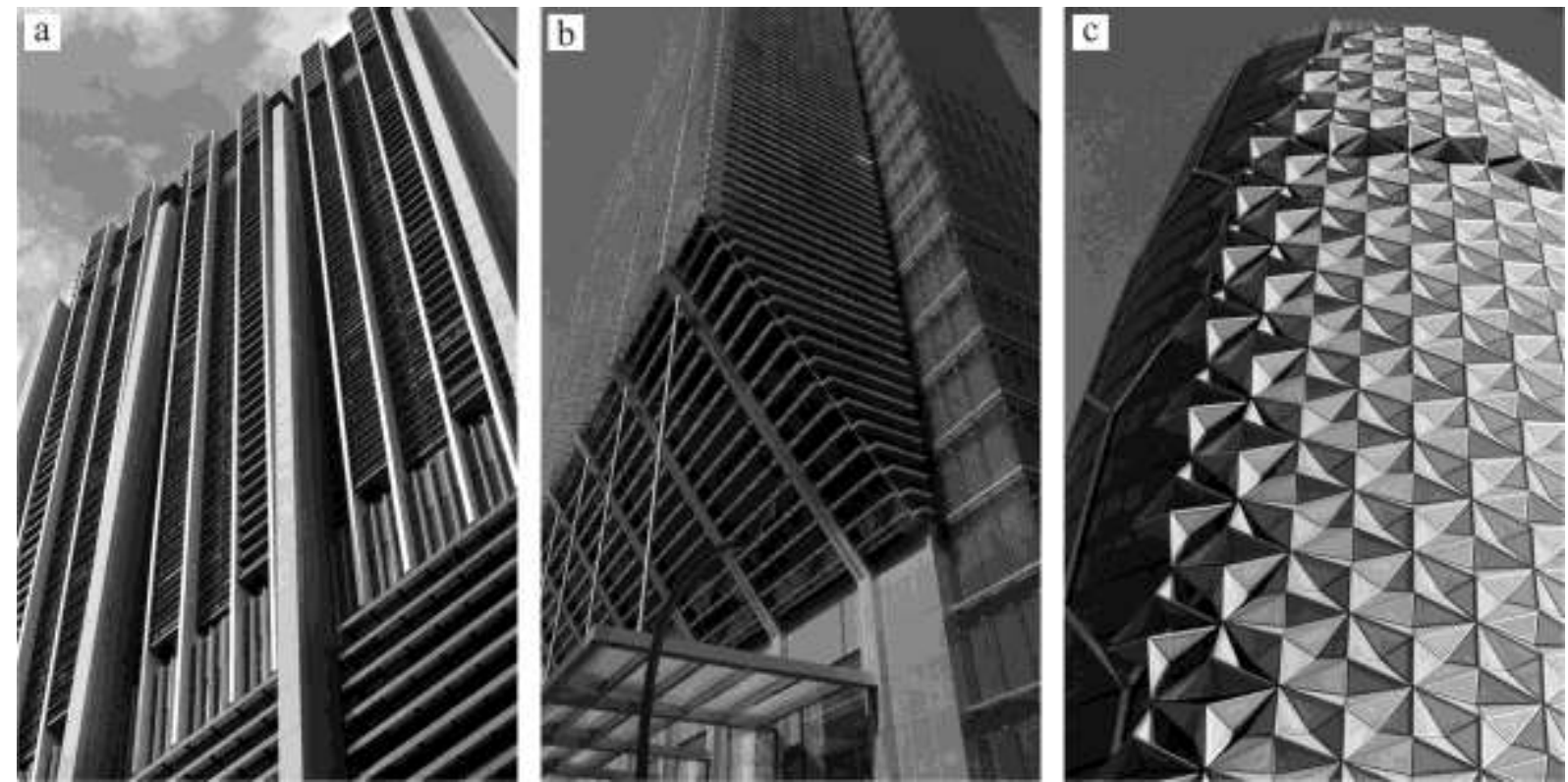

Fig.3. Skyscrapers in desert climate in the U.A.E.: a-"The Index", Dubai, architect-Foster + Partners; b-"Sowwah Square, Abu Dhabi, architect-Goettsch Partners; c-Al Bahar Tower, Abu Dhabi, architect-Aedas UK.

In this climatic zone in bioclimatic buildings movable shutters are actively used to keep the sunlight out. A high-rise complex "Al Bahar Tower" (145 m, 29 floors, completed in 2012) in Abu Dhabi, consisting of two office towers is another example of the building designed to withstand aggressive hot climate with sand storms. A distinguishing feature of the towers is a responsive dynamic facade, built of triangular screens which are combined in arrays much like umbrellas. Each array opens and closes in direct reaction to the sun's position, allowing indirect sunlight to enter the building while blocking the strongest rays. Each tower has an innovative external shading shell located at the distance of two meters from the main façade and consisting of approximately 1000 "screen umbrellas" covered with fiberglass. The screens are operated by a smart control system. In the evening all the screens are open. The shape of the tower was optimized to improve the shading system. The innovative façade of the skyscraper allows reducing the intensity of solar radiation by $50 \%$ (Fig. 3c).

C. Experiments in designing the façade systems of high-rise buildings in subtropical climate

Nowadays China is the world leader in high-rise construction. China is located in different climatic zones from subequatorial to temperate. Shanghai, one of China's largest cities, has humid subtropical climate with monsoon features. The seasons are distinct -winter, spring, summer and autumn. The lowest temperature in winter is $-10^{\circ} \mathrm{C}$. It often snows. The average temperature in summer is + $32^{\circ} \mathrm{C}$. Annual rainfall is $1149 \mathrm{~mm}$.
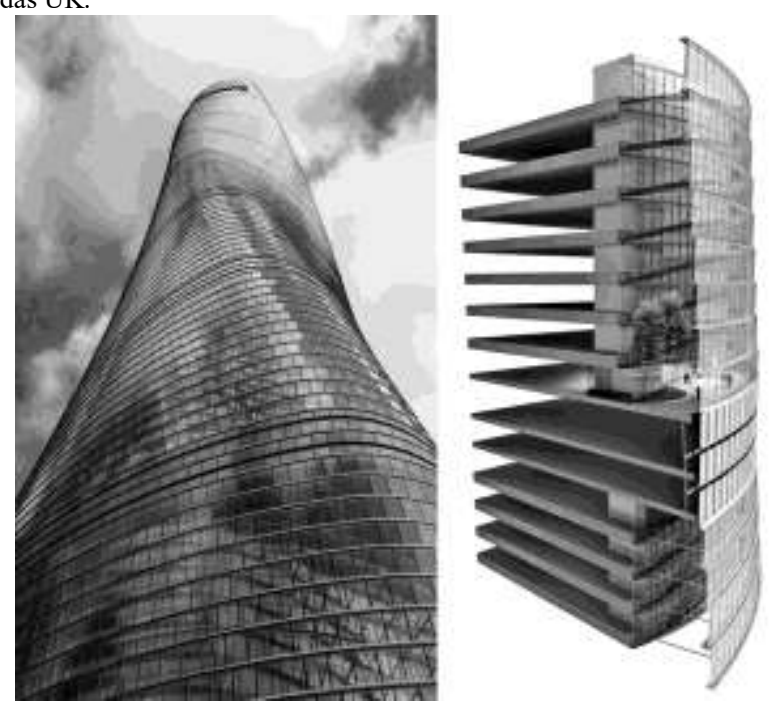

Fig.4. «Shanghai Tower», China, Shanghai, architect - Gensler (Photo: C Gensler via CTBUH)

"Shanghai Tower" (632 m, 121 floors, completed in 2015) is one of the most advanced highrise buildings in the world (Fig.4). The concept of environmental sustainability and energy efficiency of the tower is based on the integrated approach and meets the requirements of "green" standards. The greening degree of this megatall building is estimated at $33 \%$. Numerous innovations concerning constructive, space-planning and engineering characteristics were introduced. To reduce wind loads the tower is twisted in a spiral, making a turn of $120^{\circ}$. Wind turbines with vertical axis of rotation located in the top of the tower can generate up to $350000 \mathrm{kWh}$ of extra electrical power annually. Geothermal energy is used. At that the key element of the bio-climatic concept that allows reducing the need for heating and air conditioning is an innovative transparent double skin façade. The envelope structure consists of two 
independent glass layers. The outer layer determines the curved shape of the design while the inner layer has the correct round shape. The space between the layers forms ventilated landscaped atriums that improve air quality, create visual links between the city and the tower's interior. The atriums represent multi-functional public spaces- the "urban areas" for this vertical city. Energy-saving low-e glass is used. The issue of sunlight reflection on neighboring buildings by curved glass facades was carefully considered. This kind of façade reflects much less light than the smooth one [15].

D. Experiments in designing façade systems of highrise buildings in temperate continental climate

The construction of high-rise buildings in temperate continental climate has some peculiar features as this kind of climate is characterized by hot summers and frosty winters. The temperature fluctuation during the year is from $-35^{\circ} \mathrm{C}$ to $+34^{\circ} \mathrm{C}$. A striking example of a responsible environmental approach and reasonable use of combined airconditioning system is an office building "Manitoba Hydro Place" (114.9 m; 22 floors; completed in 2008), located in the center of Winnipeg in Canada. The introduction of double skin façade technology refutes the skepticism referring to its efficiency under such climatic conditions.

The key innovative solution is a double envelope of the building. The inner layer with single glazing is separated from the glazed unit of the outer layer by a buffer zone of one meter width. In winter, when the façade is sealed, it acts as a solar collector. Without using active heating the temperature in the space between the facades reaches $+20^{\circ} \mathrm{C}$ even if the temperature outdoors is below $-25^{\circ} \mathrm{C}$. "Solar ventilation" is used for effective air circulation in the system of natural ventilation of the building. Solar chimney is introduced in the building. It represents a shaft of $115 \mathrm{~m}$ height (Fig.5). The exhaust air is removed from the building through this "solar vent" through solar radiation heating. Heating and cooling system is based on using the geothermal heat of the earth. Three atrium recreation zones of $24 \mathrm{~m}$ height are constructed in the building. They are a part of the natural ventilation system. The atriums have artificial "waterfalls" that regulate the humidity indoors. A systemic design approach to this object makes it possible to minimize and even abandon the use of air conditioning systems and save $70 \%$ of energy in comparison with a typical large office tower $[16,17]$.

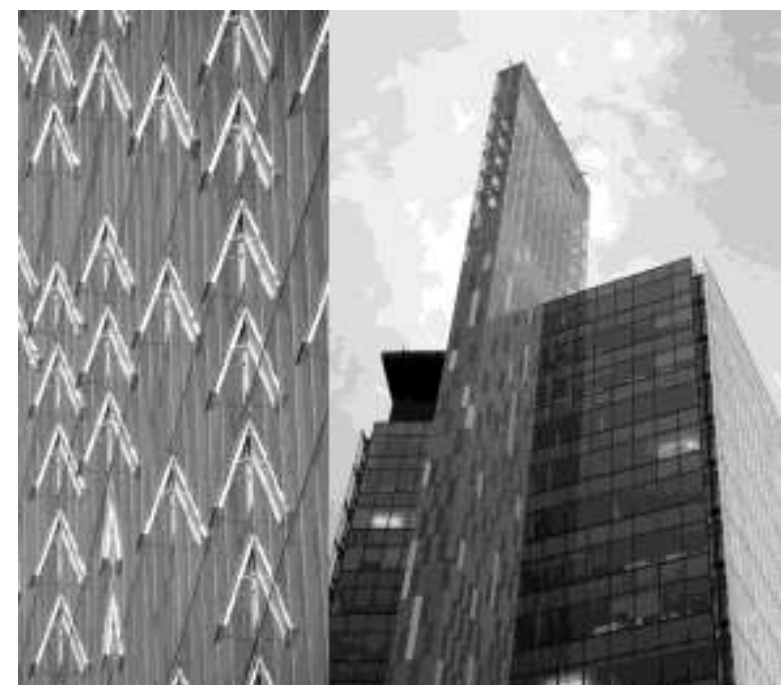

Fig.5. «Manitoba Hydro Place», Canada, Winnipeg, Kuwabara Payne McKenna Blumberg Architects.

\section{CONCLUSION}

1. The basis of designing a new generation of innovative modern high-rise buildings is a system analysis of climatic factors that link the townplanning, space-planning, construction, engineering and technological solutions into a single urban concept.

2. Despite comprehensive design solution and the combination of climatic elements the envelop façade system acts as a key element of climate adaptation and energy saving in bioclimatic highrise buildings.

3. The most promising trend is the use of multilayer ventilated facade systems, i.e. double skin facades adapted to different climatic conditions.

4. Experiments on adapting double skin façades to the climatic conditions are conducted in the following areas: 1-selecting the type of outer and inner layers (single glazing, glazed unit, fragment glazing, perforation, dynamic structure, etc.); 2introduction of passive shading in the building envelopes or in the space between them, active shading, landscaping, etc.; 3-the introduction of a unique system for natural ventilation, for example, a wind scoop or a solar chimney acting along with the double skin façade.

5. Huge power consumption of traditional skyscrapers makes architects and engineers search for new constructive systems, technologies and building materials. Being unique the objects described in this study are not single innovative projects. They represent the new typology of high-rise buildings for sustainable development of urban environment being formed on the compact, adaptive, energy efficient and ecological principles. . 


\section{REFERENCES}

[1] Generalov V.P., Generalova E.M. Sustainable architecture. Energy efficiency and sustainability of affordable housing on the example of Hong Kong. Urban Construction and Architecture, 4 (21), 2015, pp.32-38.

[2] Zhigulina A.Y. Foreign and home experience in designing energy efficient residential houses. Urban Construction and Architecture, 1, 2011, pp. 29-30.

[3] Vavilova T. A. The principle of environmental compliance as the condition for the development of high technologies, Scientific Journal of the Volga Region, 2, 2010, pp. 110-116.

[4] Generalova E.M., Generalov V.P., Kuznetsova A.A. Modular buildings in modern construction. Procedia Engineering, V. 153, 2016, pp. 167-172.

[5] Generalova E., Generalov V., Potienko N. Affordable housing under shaping dense vertical urbanism. Proceedings of the CTBUH 2016 International Conference; Shenzhen, Guangzhou, Hong Kong, China 16-20 October 2016. Volume I, 2016, pp. 650-659.

[6] Balzannikov M.I., Sosina T.N., Chumachenko N.G. Cluster «Ecoindustry»: the analyses of basic parameters, Environment for us and future generations: Works of XII International Conference, SSUACE, Samara, 2007, pp. 99102.

[7] Generalov V.P., Generalova E.M. Revealing the special features of the concepts «comfortable living» and «comfortable living environment». Urban Construction and Architecture, 2(23), 2016, pp. 85-90.

[8] Holdsworth B. Ecological high-rise: Solar architects of the 21 st century: Dr. Ken Yeang Refocus, Volume 6, Issue 1, 2005, pp. 58-60.

[9] Lotfabadi P. High-rise buildings and environmental factors. Renewable and Sustainable Energy Reviews, V.38, 2014, pp. 285-295.
[10] Wood A. Rethinking the Skyscraper in the Ecological Age: Design Principles for a New High-Rise Vernacular. Proceedings of the CTBUH 2014 Shanghai Conference «Future Cities: Towards Sustainable Vertical Urbanism». Shanghai, China. 16th-19th September 2014, pp. 26-38.

[11] Lotfabadi P., Alibaba H.Z., Arfaei A. Sustainability; as a combination of parametric patterns and bionic strategies. Renewable and Sustainable Energy Reviews, V.57, 2016, pp. 1337-1346.

[12] Broduch M.M., Engineering equipment of high-rise buildings. Under editorial of M.M. Broduch, M, AVOK-PRESS, 2007, $320 \mathrm{p}$.

[13] Capita Green. Green Features. [Online]. Available: $\mathrm{http}: / /$ capitagreensingapore.com/green-features/ [Accessed: Jan. 9, 2016].

[14] Sowwah Square, Abu Dhabi. [Online]. Available: http://www.ctbuh.org/TallBuildings/FeaturedTallBuildings/F eaturedTallBuildingArchive2013/SowwahSquareAbuDhabi/t abid/6065/language/en-US/Default.aspx [Accessed: Jan. 9, 2016].

[15] Shanghai Tower Façade Design Process. [Online]. Available: http://www.gensler.com/uploads/documents/Shanghai Tower Facade_Design_Process_11_10_2011.pdf [Accessed: Jan. 9, 2016].

[16] Kuwabara B., Auer T., Akerstream T., Clim G. And others. The conquest of climate. [Online]. Available: http://zvt.abok.ru/upload/pdf_articles/7.pdf [Accessed: Jan. 9, 2016].

[17] Brodach M.M., Shilkin N.V., Double glass facades. [Online]. Available: http://zvt.abok.ru/upload/pdf_articles/201.pdf [Accessed: Jan. 9, 2016]. 